\title{
ISOLASI DAN KARAKTERISASI LIPASE DARI REBUNG BAMBU BETUNG Dendrocalamusasper
}

\section{ISOLATION AND CHARACTERIZATION LIPASE FROM BAMBOO SHOOTS BETUNG Dendrocalamusasper}

\author{
Agung Prasetyo", Winni Astuti dan Chairul Saleh \\ ${ }^{1}$ Jurusan Kimia, Fakultas Matematika dan Ilmu Pengetahuan Alam Universitas Mulawarman, Samarinda \\ *Corresponding Author: me.agungprasetyo@gmail.com
}

Submit : 29 Oktober 2017 Accepted : 06 November 2017

\begin{abstract}
This research was conducted to get the extract of rough lipase produced by bamboo shoots (Dendrocalamus asper). Lipase isolation from bamboo shoots was done by blending bamboo shoots to produce the crude extract of the enzyme. Lipase crude extracts that occurred at centrifugation at $12000 \mathrm{rpm}$ for 30 minutes at $4^{\circ} \mathrm{C}$. The crude extracts obtained were then tested using quantitative $\mathrm{pH} 7$, temperature $30^{\circ} \mathrm{C}$ and substrate $1 \%(\mathrm{v} / \mathrm{v})$. Based on research there is activity of crude extract of lipase equal to $2,24 \mathrm{U} / \mathrm{ml}$.
\end{abstract}

Keywords : Lipase, Dendrocalamus asper, Specific Activity of Lipase.

\section{PENDAHULUAN}

Proses pertunasan atau germinasi adalah suatu proses pemecahan cadangan makanan seperti protein, lemak dan pati secara enzimatis [1]. Dalam pertumbuhan tunas memerlukan energi dan energi tersebut dihasilkan dari perombakan bahan-bahan organik oleh enzim. Enzim-enzim tersebut antara lain protease, lipase dan amilase.

Lipase merupakan enzim yang mampu menghidrolisa ikatan ester terutama lemak netral seperti trigliserida [2]. lipase dapat diaplikasikan sebagai katalis untuk sintesis ester dan transesterifikasi minyak untuk produksi biodisel [3].

Penelitian pendahuluan yang telah dilakukan menunjukkan bahwa rebung bambu betung Dendrocalamus asper mengandung lipase yang dapat bekerja pada suhu ruang. Oleh karena itu, perlu dilakukan penelitian lebih lanjut untuk mengetahui apakah terdapat enzim lipase di dalam rebung bambu betung dan untuk mengetahui aktivitas serta karakteristik dari enzim lipase yang dihasilkan rebung bambu betung Dendrocalamus asper.

\section{METODOLOGI PENELITIAN}

Alat

Alat-alat yang digunakan dalam penelitian ini adalah spektrofotometer Visible single beam, kuvet, mikropipet (10-100 $\mu \mathrm{L})$, mikropipet (100$1000 \mu \mathrm{L}$ ), tip $100 \mu \mathrm{L}$, tip $1000 \mu \mathrm{L}$, penjepit tabung, $\mathrm{pH}$ meter, blender, sentrifuse, neraca analitik, corong kaca, beaker glass, pipet, buret, Erlenmeyer, batang pengaduk, tabung mikro, stopwatch, hot plate, magnetic stirer, gelas ukur, spatula, botol semprot, sikat tabung dan labu takar $1000 \mathrm{~mL}$.

\section{Bahan}

Bahan yang digunakan dalam penelitian ini adalah rebung bambu betung, akuades, minyak kelapa, BSA (Bovin Serum Albumin) standar, pereaksi Bradford, (Thermosentific), Alkohol 95\%, Aseton, $\mathrm{NaCH}_{3} \mathrm{COO}$ (Merck), $\mathrm{CH}_{3} \mathrm{COOH}_{(\mathrm{p})}$ (Merck), $\mathrm{Na}_{2} \mathrm{HPO}_{4} \cdot 12 \mathrm{H}_{2} \mathrm{O}$ (Merck), $\mathrm{NaH}_{2} \mathrm{PO}_{4} \cdot \mathrm{H}_{2}$ $\mathrm{O}$ (Merck), $\mathrm{KCl}$ (Merck), $\mathrm{H}_{3} \mathrm{BO}_{3}$ (Merck) dan $\mathrm{KOH}$ (Merck).

\section{Prosedur Penelitian}

\section{Isolasi Enzim dari Rebung Bambu Betung}

Rebung bambu yang telah dibersihkan dipotong kecil dan ditimbang sebanyak 250 gram lalu ditambahkan $250 \mathrm{~mL}$ buffer fosfat $0,2 \mathrm{M} \mathrm{pH}$ 7 kemudian dihaluskan dengan menggunakan blender pada kondisi dingin, setelah halus langsung disaring dengan menggunakan kertas whatmann. Residu dibuang dan filtrat diambil kemudian dipindahkan ke dalam tabung mikro yang selanjutnya di sentrifugasi pada kecepatan $12000 \mathrm{rpm}$ selama 30 menit pada suhu $4^{\circ} \mathrm{C}$. Supernatan yang dihasilkan merupakan ekstrak kasar enzim.

\section{Penentuan Konsentrasi Protein}


Penentuan konsentrasi protein berdasarkan Metode Bradford. Konsentrasi protein ditentukan dengan metode Bradford dan menggunakan BSA (Bovine Serum Albumin) sebagai protein standar.

\section{Persiapan Kurva Standar}

Kurva standar BSA dibuat dari larutan stok BSA $100 \mu \mathrm{g} / \mathrm{mL}$. Konsentrasi standar BSA yang digunakan untuk variasi penentuan konsentrasi protein adalah $(0,4,8,10,12,16,20) \mu \mathrm{g} / \mathrm{mL}$. Larutan BSA dengan masing-masing konsentrasi diambil sebanyak $500 \mu \mathrm{L}$ direaksikan dengan 500 $\mu \mathrm{L}$ reagen Bradford dan diinkubasi pada suhu ruang selama 5 menit. Setelah itu, sampel diukur absorbansinya pada panjang gelombang sekitar $595 \mathrm{~nm}$. Nilai absorbansinya diplotkan dengan kurva standar protein yang dibuat antara konsentrasi larutan BSA (C) terhadap absorbansi (A). Persamaan garis yang diperoleh dapat digunakan pada perhitungan kandungan protein enzim. Sebagai blanko digunakan akuades.

\section{Penentuan Konsentrasi Protein}

Ekstrak kasar enzim diambil sebanyak 500 $\mu \mathrm{L}$ kemudian ditambahkan $500 \mu \mathrm{L}$ reagen Bradfordlalu dihomogenkan, diinkubasi selama 5 menit pada suhu ruang. Larutan diukur absorbansinya dengan spektrofotometer pada $\lambda$ $595 \mathrm{~nm}$. Data absorbansi yang diperoleh dikonversikan pada persamaan garis dari kurva standar BSA yang telah dibuat sehingga diperoleh konsentrasi kandungan protein.

\section{Uji Aktivitas Lipase Secara Kuantitatif}

Satu unit lipase per $\mathrm{mL},(\mathrm{U} / \mathrm{mL})$ menyatakan banyaknya enzim lipase yang dapat melepaskan $1 \mu \mathrm{mol}$ asam lemak bebas per menit. Uji aktivitas enzim lipase dilakukan menggunakan metode Linfield [4] Sebanyak 0,05 $\mathrm{mL}$ minyak kelapa dan 0,05 gram gum arab dimasukkan dalam labu Erlenmeyer. Setelah itu ditambahkan $4 \mathrm{~mL}$ larutan bufferfosfat $\mathrm{pH} 7$ dan $1 \mathrm{~mL}$ larutan enzim. Selanjutnya, ditambahkan $10 \mathrm{~mL}$ aseton-alkohol (1:1) dan diaduk hingga homogen. Ditambahkan 2-3 tetes indikator pp (phenolphthalein) pada larutan yang telah diaduk. Kemudian dititrasi dengan menggunakan $\mathrm{KOH}$ alkoholis 0,02 M. Dihentikan titrasi pada saat warna larutan menjadi merah jambu dan tidak hilang, dicatat volume titrasinya.

\section{HASIL DAN PEMBAHASAN}

Isolasi Ekstrak Kasar Enzim dari Rebung Bambu Betung
Isolasi ekstrak kasar enzim dilakukan dengan dua tahap yaitu homogenisasi dan sentrifugasi. Rebung bambu dihomogenkan dengan cara dihaluskan menggunakan blender dengan menambahkan buffer fosfat $\mathrm{pH} 7$ sebanyak $250 \mathrm{ml}$. Hasil homogenisasi yaitu filtrat dan residu. Residu dibuang dan filtrat di sentrifugasi pada kecepatan $12000 \mathrm{rpm}$ dengan suhu $4^{\circ} \mathrm{C}$ selama 30 menit. Supernatan yang diperoleh dari hasil sentrifugasi merupakan ekstrak kasar enzim dari rebung bambu betung. Sentrifugasi adalah teknik pemisahan suatu bahan berdasarkan berat molekul dengan kecepatan tertentu [5]. Teknik pemisahan ini di gunakan untuk memisahkan atau memurnikan protein, partikel atau organel seluler yang bersedimentasi menurut ukuran dan bentuk relatifnya.Dengan adanya teknik ini, proses pengendapan suatu bahan akan lebih cepat dan optimum dibandingkan dengan teknik biasa.Volume ekstrak kasar yang diperoleh sebanyak $185 \mathrm{ml}$.

\section{Penentuan Konsentrasi Protein}

Pada penelitian ini didapatkan kurva standar protein BSA yang diperoleh yaituy = $0,0124 x+0,2159$ dengan $R^{2}=0,9766$.

Absorbansi ekstrak kasar lipase dari rebung bambu betung adalah 0,463. Setelah itu perhitungan konsentrasi protein dilakukan dengan mensubstitusikan absorbansi larutan yang diperoleh pada kadar protein total ke dalam persamaan regresi linier kurva standar protein BSA. Pada penelitian ini didapatkan kadar protein pada ekstrak kasar lipase dari rebung bambu betung Dendrocalamus asper sebesar 0,019 mg.

Menurut Handoko [6] kandungan protein pada rebung yang pernah diketahui sebelumnya yaitu 2,5 gram, namun pada penelitian ini didapatkan konsentrasi protein sebesar 0,019 mg. Hal ini diduga dipengaruhi oleh proses pertunasan tanaman bambu.

Proses pertunasan atau germinasi adalah suatu proses pemecahan cadangan makanan seperti protein, lemak dan pati secara enzimatis [7]. Perombakan bahan-bahan organik tersebut dilakukan oleh enzim. Enzim-enzim tersebut antara lain protease, lipase dan amilase. Proses ini dibantu oleh enzim dalam umbi. Menurut Bahri [7] enzim tersebut secara bersamaan dihasilkan tumbuhan selama proses pertunasan. 


\section{Uji Aktivitas Lipase Secara Kuantitatif}

Ekstrak kasar enzim yang telah didapat kemudian di uji pada $\mathrm{pH} 7$ dan substrat $1 \%$ (v/v). Larutan reaksi tersebut di inkubasi pada suhu $30^{\circ} \mathrm{C}$ selama 30 menit. Setelah itu di titrasi dengan $\mathrm{KOH}$ 0,02 M hingga merah muda.

Data yang didapat berupa volume titrasi yang kemudian di substitusikan kedalam rumus

$$
\text { Aktivitas lipase }(\mathrm{U} / \mathrm{ml})=\frac{(A-B) \times N \text { KOH } \times 1000}{30}
$$

Sehingga didapatkan aktivitas lipase pada $\mathrm{pH} 7$ dan substrat $1 \%$ dengan suhu $30^{\circ} \mathrm{C}$ yaitu sebesar $2,24 \mathrm{U} / \mathrm{ml}$.

\section{KESIMPULAN}

Ekstrak kasar lipase telah berhasil di isolasi dari rebung bambu betung Dendrocalamus asper dengan kadar protein sebesar 0,019 $\mathrm{mg}$ serta aktivitas lipase sebesar 2,24 U/ml pada $\mathrm{pH} 7$ dengan suhu $30^{\circ} \mathrm{C}$.

\section{SARAN}

Perlu dilakukan penelitian lebih lanjut hingga tahap pemurnian ekstrak kasar lipase serta mengetahui kondisi kerja optimum lipase dari rebung bambu betung Dendrocalamus asper.

\section{DAFTAR PUSTAKA}

[1] Winarno, F. G. (1992). Rebung: Teknologi Produksi dan Pengolahan. Jakarta: Pustaka Sinar Harapan.

[2] Sana, N. K., Hossin, E. M., \& Shaha, R. K. (2004). Identification, purification and characterization of lipase from germination oil seed (Brassica napus L.). Pakistan Journal of Biological Sciences, 7, 246-252.

[3] Damaso, M. P. (2008). Utilization of Agroindustrial Residues for Lipase Production by Solid-State Fermentation. Brazilian Journal of Microbiology.

[4] Linfield, et al. (1984). Lipid-Lipase Interaction I. Fat Splitting with Candida Rugosa. JAOCS, 61(6), 1067-1071.

[5] Bintang, M. 2010. Biokimia : Teknik Penelitian. Jakarta : Erlangga

[6] Handoko, A. 2003. BudiDayaBambuRebung. Yogyakarta. Kanisius

[7] Bahri, S. 2012. Karakteristik Enzim Amilase dari Kecambah Biji Jagung Ketan. Jurnal Natural Science. Vol 1 (1): 1-2 